\title{
Effect of Glucose on Na, K-ATPase Activity in Cultured Bovine Aortic Endothelial Cells
}

\author{
Tsukasa YAMASHITA, Fumio UMEDA, Toshiniko HASHIMOTO, \\ Toyoshi INOGUCHI, Teruaki YAMAUCHI, Kazuo MIMURA, \\ Jun WATANABE AND HAJime NAWATA \\ Third Department of Internal Medicine, Faculty of Medicine, \\ Kyushu University, Fukuoka 812, Japan
}

\begin{abstract}
The effect of high concentrations of glucose on Na,K-ATPase activity and the polyol pathway was studied using cultured bovine aortic endothelial cells. Na, K-ATPase activity was expressed as ouabain-sensitive $\mathrm{K}^{+}$uptake. A significant decrease in Na, K-ATPase activity with an intracellular accumulation of sorbitol was found in confluent endothelial cells incubated with $400 \mathrm{mg} / \mathrm{d} l$ glucose for $96 \mathrm{~h}$. However, there was no significant change in the Na, K-ATPase activity or sorbitol content of the cells incubated with $100 \mathrm{mg} / \mathrm{d} l$ glucose plus $300 \mathrm{mg} / \mathrm{d} l$ mannitol. The decrease in Na, K-ATPase induced by the high glucose concentration was restored by the simultaneous addition of $10^{-4} \mathrm{M}$ ponalrestat (ICI 128,436; Statil), an aldose reductase inhibitor. The addition of this agent also significantly reduced the increase in sorbitol induced by high glucose levels. These results suggest that the decrease in $\mathrm{Na}$, K-ATPase activity induced in cultured aortic endothelial cells by high concentrations of glucose may be caused in part by the accumulation of sorbitol.
\end{abstract}

Key words: Na,K-ATPase, Glucose, Endothelial cells.

(Endocrinol Japon 39: 1-7, 1992)

HYPERGLYGEMIA plays an important role in the pathogenesis of diabetic macro- and microangiopathies. Vascular endothelial cells are believed to act as a barrier in maintaining vascular homeostasis. Therefore, a functional change in vascular endothelial cells induced by hyperglycemia would be a key event in the development of diabetic angiopathy. The mechanism underlying the altered metabolism of vascular endothelial cells induced by hyperglycemia is not clear. The possible metabolic abnormalities include an increase in nonenzymatic glycosylation of proteins or an alteration in the metabolism of polyol and myoinositol [1,2]. Such abnormalities may be responsible for diabetic vascular complications. It is considered that hyperglycemia and the subsequent

Received: April 9, 1991

Accepted: December 20, 1991

Correspondence to: Dr. Tsukasa YAMASHITA, Third Department of Internal Medicine, Faculty of Medicine, Kyushu University, 3-1-1 Maidashi, Higashiku, Fukuoka 812, Japan. accumulation of intracellular sorbitol are closely related to the depletion of myo-inositol and a decrease in Na,K-ATPase activity, which may be an important causes of diabetic complications [3]. In the diabetic state, when circulating glucose levels are high, glucose can easily accumulate in insulin-independent tissue. The accumulated glucose is converted to sorbitol in the cells by activated aldose reductase. The increased sorbitol in the cells may then alter the activity of Na,K-ATPase. The decrease in Na,K-ATPase activity induced by polyol products further inhibits the cellular uptake of myo-inositol.

It has been also demonstrated that altered membrane Na,K-ATPase activity may be responsible for a change in the cellular receptors for hormones or growth factors, or in the physiological actions of these potent factors [4-6].

To evaluate these considerations, we studied the effect of glucose on $\mathrm{Na}$, K-ATPase activity in the presence and absence of an aldose reductase 
inhibitor in cultured bovine aortic endothelial cells as they concern the pathogenesis of diabetic angiopathy.

\section{Materials and Methods}

\section{Cell culture}

Vascular endothelial cells were scraped from the intima of the bovine thoracic aorta obtained from young calves. As previously described by our laboratory $[7,8]$, the cells were cultured in Dulbecco's modified Eagle's medium (DMEM) containing $10 \%$ heat-inactivated fetal calf serum (FCS), 100 $\mu \mathrm{U} / \mathrm{m} l$ penicillin and $100 \mu \mathrm{g} / \mathrm{m} l$ streptomycin at $37^{\circ} \mathrm{C}$ in an atmosphere of $95 \%$ air and $5 \% \mathrm{CO}_{2}$. The DMEM was replaced twice weekly. The cultured cells were identified as endothelial cells by phase contrast microscopy based on typical monolayer growth with "a cobblestone appearance" and by the detection of von Willebrand factor produced in the medium. Von Willebrand factor was determined with a von Willebrand reagent (Behring Werke AG, Marburg, FRG). When confluent, the cells were continuously subcultured by trypsinization with $0.05 \%(\mathrm{w} / \mathrm{v})$ trypsin solution. Cells from the fifth passage were used in this study. When these cells reached confluence (approximately $5 \times 10^{4}$ cells/dish), they were further cultured in DMEM containing 10\% FCS with $100 \mathrm{mg} / \mathrm{d} l$ glucose, $200 \mathrm{mg} / \mathrm{d} l$ glucose, $400 \mathrm{mg} / \mathrm{d} l$ glucose, or $100 \mathrm{mg} / \mathrm{d} l$ glucose plus $300 \mathrm{mg} / \mathrm{d} l$ mannitol for the required time.

\section{Analytical methods}

$\mathrm{Na}$, K-ATPase activity was determined by ${ }^{86} \mathrm{Rb}$ uptake according to the method previously described $[9,10] .{ }^{86} \mathrm{Rb}$ is a potassium analogue whose transport across the cell membrane is used as a marker for Na,K-ATPase activity. The fifth passage cells subcultured in 24-well culture dishes (Flow Laboratories Inc, Macheen, UA) were preincubated in DMEM with $10 \%$ FCS at $37^{\circ} \mathrm{C}$ for $30 \mathrm{~min}$. The cells were incubated for $60 \mathrm{~min}$ at $37^{\circ} \mathrm{C}$ in $1 \mathrm{ml}$ of DMEM containing $1 \times 10^{5} \mathrm{dpm} /$ dish ${ }^{86} \mathrm{Rb}$ (NEN-Products, Boston, MA; 1-11 $\mathrm{mCi} / \mathrm{mg}$ ) without or with $1 \mathrm{mM}$ ouabain (Sigma, St. Louis, MO, U.S.A.) to discriminate between ouabain-sensitive and insensitive ${ }^{86} \mathrm{Rb}$ uptake. Be- cause the ouabain-sensitive $\mathrm{K}^{+}$uptake values were too low to detect, we added $10 \%$ FCS or monensin $\left(10^{-5} \mathrm{M}\right)$ to the medium as a stimulator. Simultaneously, monensin (Sigma) or FCS was added to the various final concentrations to stimulate $\mathrm{Na}$, $\mathrm{K}$-ATPase activity. The assay was terminated by aspirating the medium and immediately washing the cells three times with ice-cold phosphatebuffered saline (PBS). The cells were then fixed at room temperature in $0.5 \mathrm{ml}$ of $6 \%(\mathrm{w} / \mathrm{v})$ trichloroacetic acid for $30 \mathrm{~min}$ and removed with a cell scraper. The incorporated ${ }^{86} \mathrm{Rb}$ radio-activity was counted in an LSC-700 liquid scintillation counter (Aloka Company, Tokyo, Japan). The method described provides a measure of potassium influx into endothelial cells via $\mathrm{Na}$, K-ATPase expressed in this study as $\mathrm{Na}$, K-ATPase activity or as ouabain-sensitive $\mathrm{K}^{+}$uptake. A fluorescent enzymatic assay was used to measure the sorbitol concentration in cultured endothelial cells as described previously [11]. Briefly, cultured endothelial cells in dishes were scraped off with a rubber spatula into $1 \mathrm{ml}$ of PBS after washing three times with PBS. The suspensions were precipitated with perchloric acid and neutralized with $3 \mathrm{M} \mathrm{K}_{2} \mathrm{CO}_{3}$. The samples were then centrifuged at $3000 \mathrm{rpm}$ for $15 \mathrm{~min}$. The supernatant was collected and 50 $\mathrm{mM}$ glycine buffer ( $\mathrm{pH} 9.4), 1.25 \mathrm{mg} / \mathrm{ml}$ nicotinamide adenine dinucleotide (NAD, Sigma) and 0.6 $\mathrm{U}$ of sorbitol dehydrogenase (Sigma, from sheep liver) were added. The mixture was incubated for $45 \mathrm{~min}$ at $37^{\circ} \mathrm{C}$ and the fluorescence was measured with a spectrofluorometer (RF-5000, Shimadzu Company, Japan) with an excitation wavelength of $340 \mathrm{~nm}$ and an emission wavelength of $460 \mathrm{~nm}$. The protein concentration in $50 \mu \mathrm{l}$ aliquots of the samples was meausred by the method previously described and a BSA standard [12]. The activity of lactate dehydrogenase $(\mathrm{LDH})$, released only on severe cellular damage, was measured at several different times during cell cultures in medium as previously described [13].

\section{Statistical methods}

Statistical analysis was carried out by Student's $t$-test. Data are shown as the mean \pm SEM and $P$ values less than 0.05 were accepted as statistically significant. 


\section{Results}

Figure 1 shows the time-dependent uptake of $\mathrm{K}^{+}$into cultured endothelial cells stimulated by $10 \%$ FCS during incubation. The total and ouabain sensitive $\mathrm{K}^{+}$uptake increased in a linear fashion until $90 \mathrm{~min}$. Therefore, ouabain-sensitive $\mathrm{K}^{+}$uptake with incubation for $60 \mathrm{~min}$ was used in subsequent experiments. We could not measure ouabain-sensitive $\mathrm{K}^{+}$uptake in the absence of stimulator of $\mathrm{Na}, \mathrm{K}-\mathrm{ATPase}$ because of its low value, and subsequent experiments were performed in the presence of a stimulator of $\mathrm{Na}$,

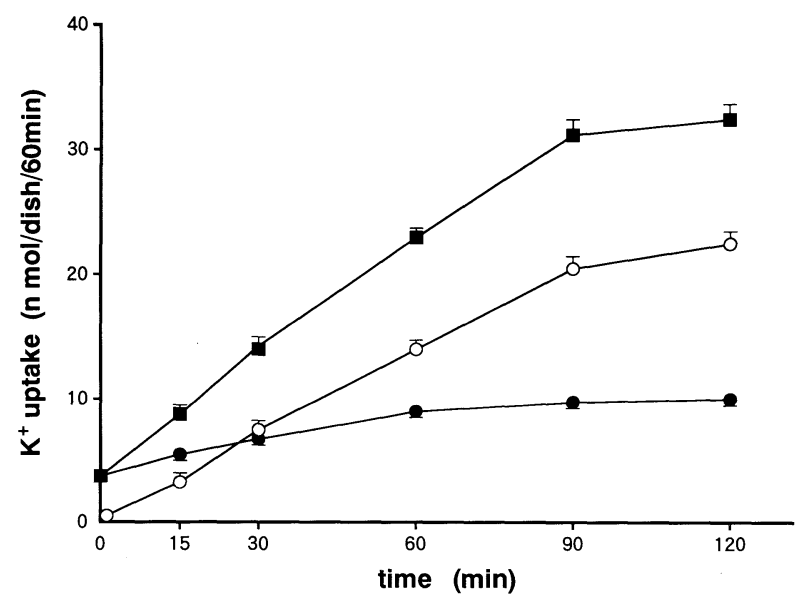

Fig. 1. Time course of $10 \%$ F(SS-stimulated $\mathrm{K}^{+}$uptake into) cultured bovine aortic endothelial cells. Fach point represents the mean \pm SEM for 5 different cell lines. Closed square shows total $\mathrm{K}^{+}$uptake, closed circle ouabain-insensitive $\mathrm{K}^{+}$uptake, and open circle ouabain-sensitive $\mathrm{K}^{+}$uptake.

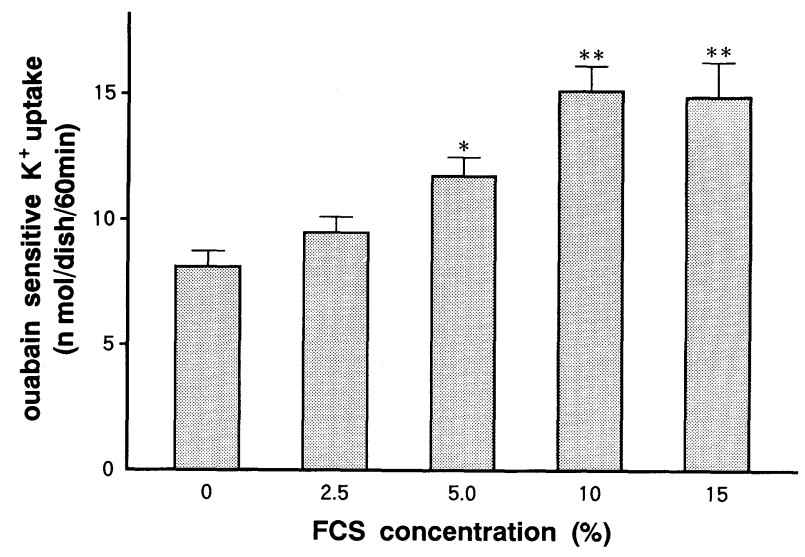

Fig. 2. Effect of $\mathrm{FCS}$ on ouabain-sensitive $\mathrm{K}^{+}$uptake of aortic endothelial cells. Bars indicate the mean \pm SEM for 5 different cell lines. Statistically significance vs. ouabain-sensitive $\mathrm{K}^{+}$uptake without FC. *, $P<0.01$; **, $P<0.001$

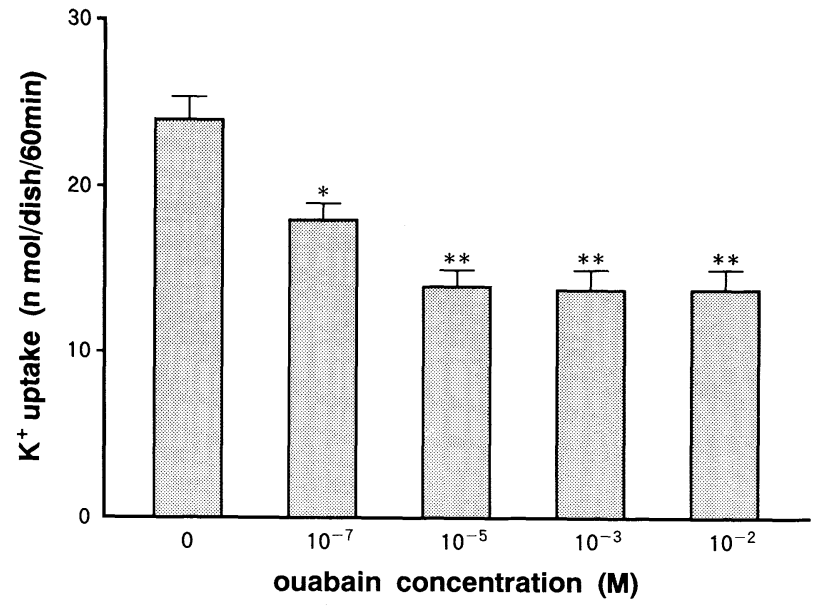

Fig. 3. Effect of ouabain on $10 \%$ FCS-stimulated $\mathrm{K}^{+}$uptake into cultured bovine aortic endothelial cells. Bars indicate the mean \pm SEM for 5 different cell lines. Statistically significant vs. $\mathrm{K}^{+}$uptake without ouabain. $*, P>0.01 ; * *, P<0.001$.

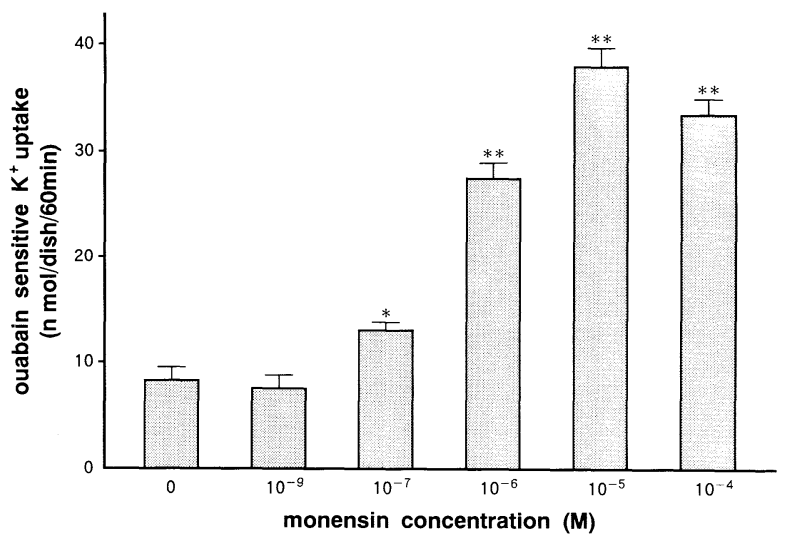

Fig. 4. Effect of monensin on ouabain-sensitive $\mathrm{K}^{+}$uptake into cultured bovine aortic endothelial cells. Bars indicate the mean \pm SEM for 5 different cell lines. Statistically significant vs. ouabain-sensitive $\mathrm{K}^{+}$uptake without monensin. *, $P<0.01 ; * *, P<0.001$

K-ATPase such as FCS or monensin. FCS stimulated the ouabain-sensitive $\mathrm{K}^{+}$uptake in a dosedependent manner. Maximal stimulation was found at a final concentration of $10 \%$ FCS (Fig. 2). Ouabain significantly inhibited the total $\mathrm{K}^{+}$uptake stimulated by $10 \%$ FCS in a dose dependent manner. The maximal inhibition of approximately $42.7 \%$ was found at a final concentration of $10^{-2}$ M ouabain (Fig. 3). Total $\mathrm{K}^{+}$uptake was inhibited from $24.1 \pm 1.1 \mathrm{nmol} / \mathrm{dish} / 60 \mathrm{~min}$ (mean $\pm \mathrm{SEM}$, $\mathrm{n}=5$ ) without ouabain to $13.8 \pm 1.3 \mathrm{nmol} / \mathrm{dish} / 60$ min with $10^{-2} \mathrm{M}$ ouabain. On the other hand, monensin as well as FCS significantly stimulated. the ouabain-sensitive $\mathrm{K}^{+}$uptake in a dose- 
dependent manner up to $10^{-5} \mathrm{M}$ (Fig. 4). The maximal stimulation by $10^{-5} \mathrm{M}$ monensin was $38.2 \pm 1.9 \mathrm{nmol} / \mathrm{dish} / 60 \mathrm{~min}$ (mean \pm SEM, $\mathrm{n}=5$ ). The monensin-stimulated ouabain-sensitive $\mathrm{K}^{+}$ uptake was inhibited by the simultaneous addition of ouabain similar to that stimulated by FCS (data not shown).

The effect of high glucose concentrations on ouabain-sensitive $\mathrm{K}^{+}$uptake was studied. Confluent endothelial cells were incubated with various concentrations of glucose or mannitol for 96 h. As shown in Fig. 5, by increasing the final concentrations of glucose from $100 \mathrm{mg} / \mathrm{d} l$ to 400 $\mathrm{mg} / \mathrm{d} l$, both the FCS- and monensin-stimulated ouabain-sensitive $\mathrm{K}^{+}$uptake were significantly decreased from $15.2 \pm 1.0 \mathrm{nmol} / \mathrm{dish} / 60 \mathrm{~min}$ (mean \pm SEM) to $9.8 \pm 1.0 \mathrm{nmol} / \mathrm{dish} / 60 \mathrm{~min}$ and from $40.0 \pm 2.0 \mathrm{nmol} / \mathrm{dish} / 60 \mathrm{~min}$ to $29.2 \pm 1.9$ $\mathrm{nmol} / \mathrm{dish} / 60 \mathrm{~min}$ after $96 \mathrm{~h}$ incubation, respectively. However, there was no significant change in ouabain-sensitive $\mathrm{K}^{+}$uptake in the cells incubated with $200 \mathrm{mg} / \mathrm{d} l$ glucose or with $100 \mathrm{mg} / \mathrm{d} l$ glucose plus $300 \mathrm{mg} / \mathrm{d} l$ mannitol as compared to those incubated with $100 \mathrm{mg} / \mathrm{d} l$ glucose (Fig. 5). In evaluating the effect of ponalrestat (ICI 128,436;

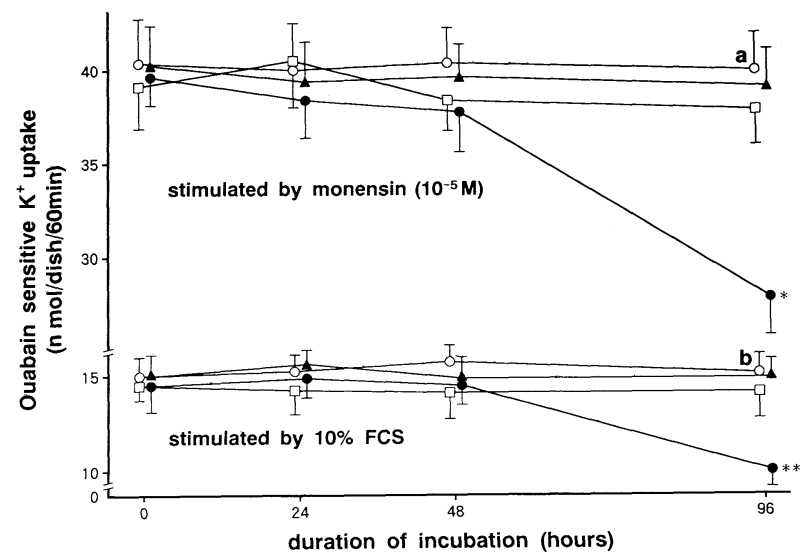

Fig. 5. Time course of monensin- and FCS-stimulated ouabain-sensitive $\mathrm{K}^{+}$uptake into cultured endothelial cells with various concentrations of glucose or mannitol. Each point represents the mean \pm SEM for 5 different cell lines. Open circle shows ouabainsensitive $\mathrm{K}^{+}$uptake into the cells with $100 \mathrm{mg} / \mathrm{d} /$ glucose; open square with $200 \mathrm{mg} / \mathrm{d} l$ glucose; closed circle with $400 \mathrm{mg} / \mathrm{d} /$ glucose; closed triangle 100 $\mathrm{mg} / \mathrm{d} /$ glucose plus $300 \mathrm{mg} / \mathrm{d} /$ mannitol. $*: \mathrm{p}<0.01 \mathrm{vs}$. a; ouabain-sensitive $\mathrm{K}^{+}$uptake of the cells cultured with $100 \mathrm{mg} / \mathrm{d} /$ glucose by monensin stimulation, **: $\mathrm{p}<0.0 \mathrm{l}$ is. b; ouabain-sensitive $\mathrm{K}^{+}$uptake of the cells cultured with $100 \mathrm{mg} / \mathrm{d} /$ glucose by $10 \%$ FCS stimulation.
Table 1. Effect of glucose and ponalrestat on ouabainsensitive $\mathrm{K}^{+}$uptake of cultured endothelial cells

\begin{tabular}{cccc}
\hline Stimulant & $\begin{array}{c}\text { Glucose } \\
(\mathrm{mg} / \mathrm{d} l)\end{array}$ & $\begin{array}{c}\text { Ponalrestat } \\
\left(10^{-4} \mathrm{M}\right)\end{array}$ & $\begin{array}{c}\text { Ouabain-sensitive } \\
\mathrm{K}^{+} \text {uptake } \\
(\mathrm{nmol} / 60 \mathrm{~min} / \mathrm{dish})\end{array}$ \\
\hline FCS & 100 & - & $14.9 \pm 1.0^{\mathrm{a}}$ \\
$(10 \%)$ & 400 & - & $15.9 \pm 1.3^{\mathrm{b}}$ \\
& 400 & + & $9.8 \pm 0.9^{\mathrm{c}}$ \\
& 100 & - & $12.4 \pm 0.6^{\mathrm{d}}$ \\
\hline Monensin & 100 & + & $36.0 \pm 1.8^{\mathrm{e}}$ \\
$\left(10^{-5} \mathrm{M}\right)$ & 400 & - & $37.8 \pm 2.2^{\mathrm{f}}$ \\
& 400 & + & $24.1 \pm 1.8^{\mathrm{g}}$ \\
& & & $30.8 \pm 1.6^{\mathrm{h}}$
\end{tabular}

Values are expressed as the mean \pm SEM $(n=5)$.

a, $P<0.01$ vs. c; c, $P<0.05$ vs. d; d, $P<0.05$ vs. b; e, $P<0.01$ vs. g; g, $P<0.05$ vs. h; h, $P<0.05$ vs $\mathrm{f}$.

Statil), an aldose reductase inhibitor, on the decreased ouabain-sensitive $\mathrm{K}^{+}$uptake by the high concentration of glucose, we observed that the decreased ouabain-sensitive $\mathrm{K}^{+}$uptake stimulated by both FCS and monensin after 96 h-incubation with $400 \mathrm{mg} / \mathrm{d} l$ glucose was significantly restored by the addition of $10^{-4} \mathrm{M}$ ponalrestat with 400 $\mathrm{mg} / \mathrm{d} l$ glucose (Table 1$)$. In contrast, no significant changes were obtained in the ouabain-sensitive $\mathrm{K}^{+}$ uptake stimulated by both FCS and monensin when ponalrestat was added to the cells incubated with $100 \mathrm{mg} / \mathrm{d} l$ glucose (Table 1). In fact, the intracellular sorbitol contents of cultured endothelial cells following incubation for $96 \mathrm{~h}$ with 400 $\mathrm{mg} / \mathrm{d} l$ glucose was increased significantly as compared to those incubated with $100 \mathrm{mg} / \mathrm{d} l$, but no statistically significant change was observed following 24 and 48 h-incubation with each concentration of glucose. Ponalrestat significantly reduced the increased sorbitol content of the cells incubated with $400 \mathrm{mg} / \mathrm{d} l$ glucose but not with 100 $\mathrm{mg} / \mathrm{d} l$ glucose (Table 2$)$. It was clear that ponalrestat reduced the increased sorbitol content and restored the decreased $\mathrm{Na}, \mathrm{K}-\mathrm{ATPase}$ activity of cultured endothelial cells exposed to high concentrations of glucose.

LDH release from the endothelial monolayer was not significantly increased after incubation with $400 \mathrm{mg} / \mathrm{d} l$ glucose for up to $96 \mathrm{~h}$ compared with $100 \mathrm{mg} / \mathrm{d} l$ glucose (data not shown). 
Table 2. Effect of glucose and ponalrestat on intracellular sorbitol content of bovine aortic endothelial cells cultured for 24,48 and $96 \mathrm{~h}$

\begin{tabular}{cccc}
\hline & Glucose $(\mathrm{mg} / \mathrm{d} l)$ & Ponalrestat $\left(10^{-4} \mathrm{M}\right)$ & Sorbitol (nmol/mg prot) \\
\hline \multirow{3}{*}{$24 \mathrm{~h}$} & 100 & $(-)$ & $15.9 \pm 1.0$ \\
& 100 & $(+)$ & $14.8 \pm 1.3$ \\
& 400 & $(-)$ & $16.6 \pm 0.9$ \\
& 400 & $(+)$ & $16.0 \pm 1.3$ \\
\hline \multirow{3}{*}{$48 \mathrm{~h}$} & 100 & $(-)$ & $16.5 \pm 1.4$ \\
& 100 & $(+)$ & $15.4 \pm 1.0$ \\
& 400 & $(-)$ & $18.7 \pm 1.2$ \\
& 400 & $(+)$ & $17.7 \pm 1.2$ \\
\hline \multirow{3}{*}{$96 \mathrm{~h}$} & 100 & $(-)$ & $16.2 \pm 1.3^{\mathrm{a}}$ \\
& 100 & $(+)$ & $24.1 \pm 1.1^{\mathrm{b}}$ \\
& 400 & $(-)$ & $18.9 \pm 1.1^{\mathrm{d}}$ \\
\hline
\end{tabular}

Values are expressed as the mean $\pm \operatorname{SE}(\mathrm{n}=5)$.

a, $P<0.01$ vs. c; c, $P<0.05$ vs. d; d, $P<0.05$ vs. b.

\section{Discussion}

Recent investigations [13, 14] have demonstrated that high concentrations of glucose induce metabolic changes in vascular endothelial cells in vitro; some of these changes may contribute to the pathogenesis of the vascular complications seen in diabetes. Na, K-ATPase plays a physiologically significant role in cellular function [15-18]. Na, $\mathrm{K}$-ATPase activity may also be altered in various other conditions such as obesity [19], essential hypertension [20], uremia [21], thyroid dysfunction [22], and aging [23].

In this study, Na,K-ATPase activity was measured as indicated by ouabain-sensitive ${ }^{86} \mathrm{Rb}$ uptake, a marker for $\mathrm{K}^{+}$uptake $[9,10]$, in cultured bovine aortic endothelial cells. Since the uptake of $\mathrm{K}^{+}$was very low when cells were incubated with the DME medium alone, we added FCS or monensin to the medium to stimulate $\mathrm{Na}$, KATPase activity. However, the exact mechanism of FCS-stimulation in aortic endothelial cells remains unclear. Concerning other types of cells, previous reports have shown that the serum contains factors that stimulate $\mathrm{Na}$, K-ATPase activity $[5,9,10$, 24-26], but the characterization and purification of the various factors have not been accomplished. Additionally, the sodium ionophore monensin stimulates ouabain-sensitive $\mathrm{K}^{+}$uptake due to the activation of $\mathrm{Na}$, K-ATPase to counteract the increase in the concentration of intracellular sodium. Ouabain-sensitive $\mathrm{K}^{+}$uptake stimulated by monensin directly indicates enzymatic activity of Na, K-ATPase and that stimulated by FCS can be thought to be a mediated hormonal receptor or an indirect expression of the activity of $\mathrm{Na}$, K-ATPase. In our study, the inhibitory effect of glucose on $\mathrm{Na}$, K-ATPase activities was shown during stimulation by both FCS and monensin. So it was suggested that the decrease in ouabainsensitive $\mathrm{K}^{+}$uptake caused by high glucose was due to the direct inhibition of enzymatic activity of $\mathrm{Na}$, K-ATPase, probably mediated by a polyol pathway.

In the present investigation, we demonstrated that a high glucose concentration reduced the $\mathrm{Na}$, K-ATPase activity of cultured endothelial cells following incubation for $96 \mathrm{~h}$. The mechanism of this effect of glucose is not fully understood but it appears to be related to the increase in intracellular sorbitol content. Furthermore, ponalrestat, an aldose reductase inhibitor (ARI), partially reduced the sorbitol content and prevented the inhibitory effect of glucose on Na, K-ATPase activity. In this study, we used aortic vascular endothelial cells relevant to the study of diabetic macroangiopathy. There are few reports on Na, K-ATPase activity and the polyol pathway in aortic tissue. Similar to our observations, it has been reported that high glucose concentrations decreased the ouabainsensitive uptake of $\mathrm{K}^{+}$into rabbit aortic intimamedia tissues; the addition of myo-inositol was indispensable for this inhibitory effect of glucose [27]. It has also been shown that in cultured 
neuroblastoma cells galactose inhibited $\mathrm{Na}, \mathrm{K}$ ATPase activity and that sorbinil, an ARI, partially restored the inhibitory effect of galactose [28]. A decrease in $\mathrm{Na}$, K-ATPase activity has also been shown in the retinal layers of diabetic subjects [29].

Following exposure to high concentrations of glucose for 5 days, cultured retinal endothelial cells showed an increase in intracellular sorbitol content and a decrease in their $\mathrm{Na}$, K-ATPase activity. The addition of sorbinil or the activation of protein kinase $\mathrm{C}$ prevented a decrease in $\mathrm{Na}$, K-ATPase activity [30]. In agreement with this finding, our study demonstrated a decrease in $\mathrm{Na}$, $\mathrm{K}$-ATPase activity by glucose in aortic endothelial cells that were incubated for longer periods (96 h) but not for shorter periods such as 24 or $48 \mathrm{~h}$. In addition the effect of ponalrestat on the sorbitol content and $\mathrm{Na}, \mathrm{K}-\mathrm{AT}$ Pase activity was found only after incubation for $96 \mathrm{~h}$. In contrast, it has been reported that a decrease in $\mathrm{Na}, \mathrm{K}$-ATPase activity of the rabbit aortic wall was found after incubation for only $30 \mathrm{~min}$ with a high concentration of glucose [27] and an increase in intracellular sorbitol content of human endothelial cells caused by a high concentrations of glucose was detected after incubation for only $6 \mathrm{~h} \mathrm{[31].} \mathrm{This} \mathrm{discrepancy} \mathrm{in}$ incubation time is thought to be caused by differences in cell type, culture conditions and by methods of analyzing $\mathrm{Na}, \mathrm{K}$-ATPase and in- tracellular sorbitol.

In our study, neither the sorbitol content nor the Na, K-ATPase activity changed in the cells incubated with physiological concentrations of glucose $(100 \mathrm{mg} / \mathrm{d} l)$. However, some reports have shown the stimulation of $\mathrm{Na}, \mathrm{K}$-ATPase activity by ARI in other tissues through other mechanisms. It was reported that the treatment of isolated rat renal glomeruli with sorbinil increased $\mathrm{Na}, \mathrm{K}$ ATPase activity in physiological conditions [32]. Moreover, another report showed a direct sitmulation by ARI of the Na, K-ATPase of bovine kidney [33]. Our last report also suggested a direct stimulation by ponalrestat of $\mathrm{Na}, \mathrm{K}$-ATPase activity of washed erythrocytes [34]. In view of these facts, a direct effect of ponalrestat on $\mathrm{Na}$, KATPase activity in cultured aortic endothelial cells cannot be ruled out. The decrease in $\mathrm{Na}$, KATPase activity of vascular endothelial cells induced by a high glucose concentration may be related to the other metabolic changes; for example, cell growth $[17,18,35,36]$, prostacyclin generation [37] and endothelin production to mention but a few possibilities [38]. These functional alterations, including the decrease in $\mathrm{Na}$, $\mathrm{K}$-ATPase activity in vascular endothelial cells, may be involved in the pathogenesis of diabetic angiopathy.

\section{References}

1. Koh MS, Misch KJ, Yuen CT, Rhodes EL (1986) Accumulation of sorbitol in endothelial cells-a possible cause of diabetic microangiopathy. Diabetes Res 3: 27-219.

2. Lorenzi M, Toledo S, Boss GR, Lane MJ, Montisano DF (1987) The polyol pathway and glucose-6phosphate in human endothelial cells cultured in high glucose concentrations. Diabetologia 30: 222-227.

3. Winegard AI (1987) Does a common mechanism induce the diverse complications of diabetes? $\mathrm{D} i$ abetes 36: 396-406.

4. Jourdheuil R, Mourayre Y, Vague P, Boyer J, Vague IJ (1987) In vivo insulin effect on ATPase activities in erythrocyte membrane from insulindependent diabetics. Diabetes 36: 991-995.

5. Mario A, De Luise M, Harker M (1988) Insulin stimulation of $\mathrm{Na}^{+},-\mathrm{K}^{+}$pump in clonal rat osteosarcoma cells. Diabetes 37: 33-37.

6. Ono H, Umeda F, Inoguchi T, Ibayashi H (1989)
Decrease in insulin binding to aortic endothelial cells cultured with high glucose concentration. Diabetes Res Clin Pract 6: 115-119.

7. Inoguchi $\mathrm{T}$, Umeda $\mathrm{F}$, Ono $\mathrm{H}$, Kunisaki M, Watanabe J, Nawata H (1989) Abnormality in prostacyclin-stimulatory activity in sera from diabetics. Metabolism 38: 837-842.

8. Umeda F, Inoguchi T, Nawata H (1989) Reduced stimulatory activity on prostacyclin production by cultured endothelial cells in serum from aged and diabetic patients. Atherosclerosis 75: 61-66.

9. Rozengurt E, Heppel LA (1975) Serum rapidly stimulates ouabain- sensitive $\mathrm{Rb}$ influx in quiescent 3T3 cells. Proc Natl Acad Sci USA 7: 4492-4495.

10. De Luise M, Harker M (1986) Parathyroid hormone stimulation of the Na, K-ATPase pump in clonal osteosarcoma cells. J Endocrinol 111: 61-66.

11. Malone JI, Knox C, Benords S, Tedesco TA (1980) Red cell sorbitol: an indication of diabetic control. Diabetes 9: 861-864. 
12. Lowry DH, Rosebrogh J, Farr Al, Randall RJ (1951) Protein measurements with the folin phenol reagents. J Biol Chem 193: 265-275.

13. Lorenzi M, Cagliero E, Toledo S (1985) Glucose toxicity for human endothelial cells in culture. Diabetes 34: 621-627.

14. Lorenzi M, Montisano DF, Toledo S, Barrieux A (1986) High glucose induces DNA damage in cultured human endothelial cells. J Clin Invest 77: 322-325.

15. Elligsen JD, Thompson JE, Frey HE, Kruuv J (1974) Correlation of $\left(\mathrm{Na}^{+}, \mathrm{K}^{+}\right)$-ATPase activity with growth of normal and transformed cells. Exp Cell Res 87: 233-240.

16. Balban RS, Bader JP (1984) Studies on the relationship between glycolysis and $\left(\mathrm{Na}^{+}, \mathrm{K}^{+}\right)$-ATPase in cultured cells. Biochim Biophys Acta 804: 419-426.

17. Kirk JL, Wenner CE, Tomei LD (1985) Correlation of ouabain-sensitive ion movements with cell-cycle activation. Proc Natl Acad Sci USA 82: 1599-1603

18. Fava P, Geck P, Brandle K, Hahn JB (1988) Density- related changes of amphibian endothelial cells. J Cell Physiol 136-111-117.

19. De Luise M, Blackburn GL, Flier JS (1980) Reduced activity of the red-cell sodium-potassium pump in human obesity. N Engl J Med 1017-1022.

20. Mahoney JR, Etkins NL, McSwigan JD, Eaton JW (1982) Assessment of red cell sodium transport in essential hypertension. Blood 59: 439-444.

21. Izumo H, Izumo S, De Luise M (1984) Erythrocyte $\mathrm{Na}$, K pump in uremia acute correction of transport defect by hemodialysis. J Clin Invest 74 : 581-588.

22. De Luise M, Flier JS (1984) Status of the red cell $\mathrm{Na}, \mathrm{K}$-pump in hyper- and hypothyroidism. Metabolism 32: 25-30.

23. Vomel T (1984) Properties of ATPase and energyrich phosphates in erythrocytes of young and old individuals. I Gerontol 30: 22-25.

24. Fehlmann M, Freychet $P$ (1981) Insulin and glucagon stimulation of (Na-K)-ATPase transport activity in isolated rat hepatocyte. J Biol Chem 256: 7449-7453.

25. Nenand KR, Mary L, Pollet RJ (1985) The mechanism of insulin stimulation of $(\mathrm{Na}, \mathrm{K})$ ATPase transport activity in muscle. $J$ Biol Chem 260: 6206-6212.

26. Turaihi K, Baron DN, Dandona P (1988) Effect of glucose intake on human leukocyte ${ }^{86} \mathrm{Rb}$ influx and $\left[{ }^{3} \mathrm{H}\right]$-ouabain binding. Metabolism 37: 171-174.
27. Simmons DA, Winegard AI (1989) Mechanism of glucose-induced $\left(\mathrm{Na}^{+}, \mathrm{K}^{+}\right)$-ATPase inhibition in aortic wall of rabbits. Diabetologia 32: 402-408.

28. Mark AY, Dunlup JA (1989) Effect of galactose and glucose levels and sorbinil treatment on myo-inositol metabolism and $\mathrm{Na}, \mathrm{K}$ pump activity in cultured neuroblastoma cells. Diabetes 38: 996-1004.

29. MacGregor LC, Matschinsky FM (1986) Altered retinal metabolism in diabetes. Measurement of ( $\mathrm{Na}, \mathrm{K})$-ATPase and total sodium and potassium in individual retinal layers. $J$ Biol Chem 261: 4052-4058.

30. Lee TS, MacGregor LC, Fluharty SJ, King GL (1989) Differential regulation of protein kinase C and ( $\mathrm{Na}, \mathrm{K}$ )-adenosine triphosphate activities by elevated glucose levels in retinal capillary endothelial cells. J Clin Invest 83: 90-94.

31. Hawthorne GC, Bartlett K, Hetherington CS, Alberti KGMM (1989) The effect of high glucose on polyol pathway activity and myo-inositol metabolism in cultured human endothelial cells. Diabetologia 32: 163-166.

32. Cohen MP, Klepser H (1988) Glomerular Na, K-ATPase activity in acute and chronic diabetes and with aldose reductase inhibition. Diabetes 37 : 558-562.

33. Margaret HG, Spector A (1987) Direct stimulation of Na, K-ATPase and its glucosylated derivative by aldose reductase inhibitor. Diabetes 36: 716-720.

34. Umeda F, Noda K, Hashimoto T, Yamashita T, Nawata H (1989) Effect of aldose reductase inhibitor (ponalrestat) on erythrocyte $\mathrm{Na}$, K-ATPase activity in non-insulin-dependent diabetic patients with polyneuropathy. Diabetes Res Clin Pract 12: 125-129.

35. Kaplan JG (1987) Membrane cation transport and the control of proliferation of mammalian cells Annu Rev Physiol 40: 19-41.

36. Koch KS, Leffert HL (1979) Ionic landmarks along the mitogenic route. Nature (Lond) 279: 104-105.

37. Nakagawa M, Takatsu H, Toyoda T (1986) Effect of inhibition of Na-K ATPase on the prostacyclin generation of cultured human vascular endothelial cells. Life Sci 40: 351-357.

38. Yamauchi T, Ohnaka K, Takayanagi R, Umeda F, Nawata H (1990) Enhanced secretion of endothelin-1 by elevated glucose level from cultured bovine aortic endothelial cells. FEBS Lett 267: $16-18$. 